\title{
Brain Natriuretic Peptide Measurement
}

National Cancer Institute

\section{Source}

National Cancer Institute. Brain Natriuretic Peptide Measurement. NCI Thesaurus. Code C74735.

The determination of the amount of brain natriuretic peptide present in a sample. 